\title{
SUBJECTIVITIES AND CHALLENGES OF PEOPLE LIVING WITH AN INTESTINAL OSTOMY
}

\author{
Ana Lúcia da Silva1,* (D), Ana Beatriz Duarte Vieira (D), Ritielly Hevelin Garrido

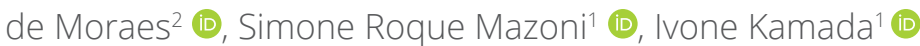

\begin{abstract}
Objective: Identify experiences of the person with intestinal ostomy related to their social life. Methods: Descriptive study, qualitative in nature, carried out with ten people with intestinal ostomy. Data collection was performed at the Stomatherapy Service of a teaching hospital in the Federal District, through semi-structured interviews relating to family and social experience before and after the ostomy. Results: Six men and four women participated, with a mean age of 49 years, most with a permanent colostomy. From the analysis, two categories emerged: "What is it like to live with an ostomy and its challenges"; and "Strategies developed in the face of changes". In the first category, the following stand out: self-care, lack of adequate bathroom, work activity, eating habits, disruption of body image and embarrassing situations. In the second category, they seek to support religiosity, maintain positive feelings and preserve emotional balance. Conclusion: The ostomy interferes with family and social life. It was evident that the person with ostomy develops strategies to face changes. It is believed that social isolation stems, in part, from the lack of information from society, the lack of quality material that offers comfort and safety, and, finally, the lack of adapted public and private bathrooms.
\end{abstract}

DESCRIPTORS: Ostomy. Adaptation. Nursing. Stomatherapy.

\section{SUBJETIVIDADES E DESAFIOS DE PESSOAS CONVIVENDO COM ESTOMIA INTESTINAL}

\section{RESUMO}

Objetivo: Identificar vivências da pessoa com estomia intestinal relacionadas ao seu convívio social. Métodos: Estudo descritivo, de natureza qualitativa, realizado com dez pessoas com estomia intestinal. A coleta de dados foi realizada no Serviço de Estomaterapia de um hospital escola do Distrito Federal, por meio de entrevistas semiestruturadas relativas à vivência familiar e social antes e após a estomia. Resultados: Participaram seis homens e quatro mulheres, com idade média de 49 anos, a maioria com colostomia definitiva. Da análise surgiram duas categorias: "Como é viver com estomia e seus desafios"; e "Estratégias desenvolvidas diante das mudanças". Na primeira categoria destacam-se: autocuidado, falta de banheiro adequado, atividade laboral, hábitos alimentares, ruptura da imagem corporal e situações constrangedoras. Na segunda categoria buscam: apoiar na religiosidade, manter sentimentos positivos e preservar o equilíbrio emocional. Conclusão: A estomia interfere no convívio familiar e social. Ficou evidente que a pessoa com estomia desenvolve estratégias para enfrentar as mudanças. Acredita-se que o isolamento social decorre, em parte, pela falta de informação junto à sociedade, falta de material de qualidade que ofereça conforto e segurança e, por último, falta de banheiros, públicos e privados, adaptados.

DESCRITORES: Estomia. Adaptação. Enfermagem. Estomaterapia.

1. Universidade de Brasília - Faculdade de Ciências da Saúde - Departamento de Enfermagem - Brasília (DF), Brazil.

2. Universidade de Brasília - Faculdade de Ciências da Saúde - Brasília (DF), Brazil.

*Correspondence author: analucia@unb.br

Section Editor: Isabel Cristina R V Santos

Received: Mar. 2021, 24 | Accepted: Jun. 2021, 21

How to cite: Silva AL; Vieira ABD; Moraes RHG; Mazoni SR; Kamada I. Subjetividades e desafios de pessoas convivendo com estomia intestinal. ESTIMA, Braz. J. EnterostomalTher., 2021, 19: e1721. https://doi.org/10.30886/estima.v19.1034_IN 


\section{SUBJETIVIDADES Y RETOS DE LAS PERSONAS QUE VIVEN CON OSTOMÍA INTESTINAL}

\section{RESUMEN}

Objetivo: Identificar experiencias de la persona con ostomía intestinal relacionadas con su vida social. Método: Estudio descriptivo, de carácter cualitativo, realizado con diez personas con ostomía intestinal. La recolección de datos se realizó en el Servicio de Estomaterapia de un hospital universitario del Distrito Federal, mediante clasificaciones semiestructuradas relacionadas con la experiencia familiar y social antes y después de la ostomía.. Resultados: Participaron seis hombres y cuatro mujeres, con una edad promedio de 49 años, la mayoría con colostomía definitiva. Del análisis surgieron dos categorías: cómo es vivir con una ostomía y sus desafíos; y Estrategias desarrolladas ante los cambios. En la primera categoría destacan: autocuidado, falta de baño adecuado, actividad laboral, hábitos alimentarios, alteración de la imagen corporal y situaciones embarazosas. En la segunda categoría, buscan: apoyar la religiosidad, mantener sentimientos positivos y preservar el equilibrio emocional. Conclusión: La ostomía interfiere en la vida familiar y social. Fue evidente que una persona con ostomía desarrolla estrategias para enfrentar los cambios. Se cree que el aislamiento social se debe en parte a la falta de información con la sociedad, a la falta de material de calidad que ofrezca comodidad y seguridad y, finalmente, a la falta de baños públicos y privados adaptados.

DESCRIPTORES: Estomía. Adaptación. Enfermería. Estomaterapia

\section{INTRODUCTION}

Intestinal ostomy is a surgical intervention that consists of an abdominal opening, allowing the exteriorization of an intestinal segment for the exit of feces ${ }^{1}$.

Epidemiological data indicate scarcity of statistics, official data are few. Currently, it is possible to find information on the social networks of state associations and the Ministry of Health, that there are approximately 400 thousand people with ostomy in Brazil. According to Santos ${ }^{2}$, following the methodology of the International Ostomy Association, Brazil would have about 170 thousand people with ostomy, according to the 2000 census $^{2}$.

The creation of an ostomy entails significant changes in the experience of people with an ostomy and requires adjustment to their new routine. Thus, they often manifest insecurity in social life, in returning to work activities, in adjusting their eating habits and in self-care, which involves hygiene and the use of collecting equipment. Thus, psychological support for people with ostomy is essential to facilitate their readaptation and acceptance of the new way of life ${ }^{3}$. The ostomy consists of the surgical construction of a new path for the exit of feces and is named according to its anatomical location. Thus, it is called colostomy when the opening is made in the colon and ileostomy when it is in the ileum ${ }^{4}$.

People with intestinal ostomy face problems that are characterized by involuntary eliminations that result in imbalances and health problems. In addition, they may feel stigmatized, with tendencies towards social isolation, not only to avoid embarrassing situations for themselves, but also to avoid likely embarrassment to friends and family

Thus, it is necessary to pay more attention to people with ostomy, seeking, in their universe, to know and understand the meaning of their experiences related to family and social aspects to provide them with opportunities to express their feelings, in order to encourage physical and emotional readaption ${ }^{5}$. In view of these circumstances, concerns emerged that led to the elaboration of the guiding question: what is the person's perception of their daily lives after being submitted to an ostomy?

Therefore, it is necessary to understand the ostomy patient's needs to establish a comprehensive and continuous care plan. Through educational actions, coherent and real information should be offered to patients and their families, improving their understanding of the subject, a fact that only research can provide.

The chosen theme of this study sought to understand the person in their subjectivity, in the process of being ostomized within a social context. Based on the authors' experience, it is justified to know the significant changes and new behaviors 
assumed by the person after the therapeutic intervention in making a stoma, whether temporary or permanent. This research aimed to identify the experiences of people with intestinal ostomy related to social aspects.

\section{METHODS}

Descriptive and exploratory study, with a qualitative approach, carried out in the Outpatient Service of Nursing in Stomatherapy of a public hospital in the teaching network of the Federal District. Inclusion criteria were: accepting to participate in the study after receiving the researcher's invitation; being 18 years old or older, of both genders; having an intestinal ostomy for at least six months; be literate; spoken and written fluency in the Portuguese language; be able to provide information through the interview; being a user of the stomatherapy service, the research scenario. This service is part of a permanent extension project, coordinated by professors and researchers, with the participation of nurses from the service and undergraduate nursing students. It offers specialized and comprehensive nursing care for people with ostomy, wounds and urinary and anal incontinence. A minimum time of six months was established for the person to be able to report their family and social experience before and after the ostomy.

Data were collected through individual semi-structured interviews, in the period between April and August 2019. An instrument developed by the authors was used, with questions about socio demographic data and open questions related to family and social experience before and after the ostomy.

The interviews were scheduled according to the participant's convenience and held in a reserved place. To protect the identity of the interviewees, a codification was created, which was named with the letter $\mathrm{E}$ followed by numerical order, according to the sequence of interviews. Data collection ended when saturation occurred, that is, the respondents' answers began to repeat themselves.

To apprehend the perception of the participants in relation to their daily life with the ostomy, the Bardin6 content analysis technique was used, looking for meaning in the speeches, following three steps: pre-analysis, exploration of the material and treatment of results. In the first phase, the transcription of the interviews in full was organized, then the content was read with detailed analysis and the themes that were repeated frequently and the units of meaning were selected. In the second phase, the themes were grouped. In the third phase, the interpretation of these groups took place through theoretical foundations.

This study is linked to the project "Social and sexual aspects experienced by people with elimination ostomy", approved by the Research Ethics Committee under number 3.052.661/2019, and all participants signed the Informed Consent Form.

\section{RESULTS}

Ten people with intestinal ostomy attended at the Stomatherapy Service of a teaching hospital in the Federal District were interviewed, 6 men and 4 women. The mean age of patients was 49 years, minimum 30 and maximum 60 years. As for marital status, $50 \%$ were single, $30 \%$ married and $20 \%$ widowed. The majority, $70 \%$ of the participants, had elementary education, $20 \%$ had high school and only $10 \%$ had higher education. The data referring to the types of ostomy are $90 \%$ colostomy and $10 \%$ ileostomies. The time of experience of respondents with the ostomy ranged from 6 months to 24 years, being $90 \%$ definitive and $10 \%$ temporary.

With regard to the causes of the creation of the ostomy, $40 \%$ resulted from colorectal cancer, $30 \%$ from trauma, $20 \%$ from Crohn's disease and $10 \%$ from rectal prolapse. Of the reasons that lead to the need to make an intestinal ostomy, tumors are the most frequent. In Brazil, according to data from the National Cancer Institute, there are an estimated 20,540 cases of colorectal cancer in men and 20,470 in women, for the triennium 2020-2022. These types of cancer rank 3rd among men and 2 nd among women ${ }^{7}$. Other causes can be obstructions, congenital malformations, trauma and inflammatory bowel diseases ${ }^{8}$.

After analyzing the data, supported by the content analysis technique, two categories emerged: "What is it like to live with an ostomy and its challenges" and "Strategies developed in view of the changes". 
The first category, "What is it like to live with an ostomy and its challenges", groups the participants' statements about the experience of self-care, work activity and eating habits. In addition, subjective issues related to body image, coping with embarrassing situations and leisure are highlighted.

After making the ostomy, significant changes occur in the person's way of life. They change hygiene habits due to the need for frequent emptying of the collection bag so as not to leak feces and prevent its detachment. Due to the inadequacy and inaccessibility of bathrooms in public or private places, self-care is restricted to homes only, as reported by the interviewees.

The fact is that if you don't have an adapted bathroom, it's a problem (...) When I go out, I do all the hygiene at home, I only use the bathroom when I return home. There's no way I can do it while standing! (E5)

Social life is complicated, because there are places we go that are very awkward to use the bathroom. Depending on the day, we need to use the bathroom several times... I get worried about going to the bathroom to see if the bag will fill. (E2)

It is essential that the feces collection equipment is safe and comfortable. The testimonies show that the lack of guidance and the low quality of materials pose risks and contribute to social isolation.

Once, here at home, I got up and the bag broke. It messed up, I'm glad I was at home. The other day, when I got off the bike, the clamp opened and fell to the ground, the bag had liquid that wet my shorts. I returned home quickly. It deprives me a lot, if I was the stay-at-home type, today I am even more. (E7)

In the beginning, everything is new and we are not prepared. I spent 19 years without using a bag. I used bandages, compresses and gauze (...) I had depression, I suffered a lot, I didn't have a quality of life without a bag... I used to change the dressing eight times a day, I woke up at dawn to change the dressing. It burned my skin a lot (...) I came to gain quality of life after I used the bag. (E5)

Afraid of having an accident and injuring the stoma, the interviewees create adaptation strategies to face the new condition of life.

I can't lie on my stomach, I always sleep cautiously. If I'm going to use the car's seat belt, I have to put it on in another way, from behind. If it has an impact, it forces the ostomy. (E7)

I can't hold my daughter in my arms anymore, I can't ride a bike, run... I went to the club, but I didn't go into the pool. (E10)

As for work activities, it appears that people with ostomy prefer to apply for government benefits or early disability retirement.

I didn't get a job. I'm on sick pay and in the process of retirement. (E7)

Restriction and change in eating habits are necessary after the ostomy, as food has an influence on peristalsis and bowel function. The rigorous selection of foods is recommended to control feces odor, flatulence, diarrhea and/or obstruction, thus avoiding unpleasant situations related to the ostomy. In addition, each one follows their own conceptions, resulting from learning about intestinal functioning.

"I know what foods I can’t eat, like beans, cabbage, bananas, couscous and farofa." (E10)

"When I go out, I usually eat flour so I don't do it on the street, I eat two spoons of flour and go out". (E6) 
In the social sphere, the difficulty of the person with an ostomy in resuming contact with their peers is noticeable, as there is a concern to maintain discretion and hide the ostomy. They often change their clothing style to cover up the collecting device and avoid dialoguing with strangers about their health condition.

I like to wear a looser shirt underneath, so as not to show that volume on the bag. And another one on top, because sometimes you have to raise your arm and the long shirt, sometimes, it doesn't show the bag. Because there is a bag that is transparent, when it appears it is quite embarrassing. (E1)

I have to wear longer shirts (...) When I go to the gym I wear a compression shirt that doesn't show much (...) I swim in a triathlon swimsuit. One day a guy asked: - you only come with this jumpsuit? not to mention that I wear a bag, I say that my training is different, that I take part in competitions. I try to distract them so they don't know about my problem. There are a lot of people who don't know. (E7)

The exit of gases causes noise, something that is socially discriminated, which causes people to react with disgust and embarrassment. This condition imposes feelings of shame, insecurity and concern to the person with an intestinal ostomy.

Sometimes we feel embarrassed (...) because it's something I don't have control over, gas output. So, even with the bag, one can hear that noise, whoever is next to it. This sometimes makes me ashamed (...) In the restaurant I look for a little table in the corner, far from so much movement. (E1)

The conditions for living with an intestinal ostomy are very complex. The testimonies show that, in reality, the population does not know about the problem, due to the lack of knowledge about what it is to live with an ostomy. This generates prejudice and pre-judgments.

I was wearing a tighter shirt, then some police officers came and stopped me. They lifted my shirt (...) They thought I had a gun, it has volume. (E5)

One day I was at the bank, I passed the metal detector, the guy said 'lift up your shirt, what've you got there?'Then when he saw it, oh sorry I didn't know. It's an embarrassment that we'll go through. (E7)

Social reintegration represents a major obstacle for people with an intestinal ostomy. They generally feel insecure and there is always the suspicion of being discriminated against and judged by people they are close to. Therefore, they prefer to accommodate themselves in more discreet and distant places from other people.

At the cinema, I always sit on the edge at the end, because if I need to leave, it's faster for me (...) I don't go to the club, I'm afraid to take my shirt off. (E7)

I really enjoyed bathing in the river, but lately I have limited these activities. Someone may notice and feel disgusted (...) the problem is not my movement, it's whoever may be around me that worries me. I try to put myself in the shoes of the people who are nearby. (E1)

Changes in daily life, which reduce leisure, are generally related to concerns about accessibility, rupture and leakage of the collection bag.

The frequency of going out has decreased, because I have to go to the bathroom to empty my bag, it disturbs me. I stopped going out at night. I feel uncomfortable. The friends walked away. (E4) 
I have to know if my bag is full or empty before I leave (...) if there is an adapted toilet, because the bag fills up a lot. (E7)

The second category deals with the strategies developed in the face of changes. Most seek support in religious faith. It is one of the ways to live with the new health condition for the rest of your life.

I really believe in God, in prayers. When we discover something like this with us, we cannot be discouraged, we always have to have hope, a lot of faith. More importantly, putting God first, because without Him we do nothing. (E2)

I give it to God (...) I keep my head held high, I don't let myself down. (E10)

Another way to deal with these difficulties is the reorganization and reorientation of daily life, while overcoming obstacles with positive feelings. With the creation of the stoma, participants acquire mechanisms to preserve emotional balance and refer affectionately when commenting on the stoma and gratitude for being alive.

But it was the colostomy that saved my life. Every day I thank God and this little flower here. My strategy is to accept (...) if we have a good psychological acceptance, we can be calm. (E3)

A person has to feel good and accept themselves, give thanks for being alive and move on. In the beginning I hid a lot, I went to the gate with the towel, I put on my shirt, nowadays I go shirtless. (E9)

Usually only close family members are aware of the health condition. Out of fear or concern about the reaction of people around them, most do not reveal their experiences of living with an intestinal ostomy.

I don't really like to tell people, no. In my coexistence, few people know. I think people are prejudiced. Sometimes they can be afraid of us. (E2)

People who aren't close aren't interested in knowing what the situation is, the details. Most of the time, the person is scared just to know. It's something few people know (...) I feel a little embarrassed to talk to people I don't know. (E1)

\section{DISCUSSION}

From the analysis of the participants' statements, it is evident that the intestinal ostomy changes people's daily lives and provokes different emotional reactions. In addition, there are physical changes that affect social life. Thus, it is necessary that professionals are qualified to help them prepare to live with an ostomy for the rest of their lives.

In the category "What is it like to live with an ostomy and its challenges", it is clear that self-care represents a challenge for those who live with an intestinal ostomy, as it means handling feces on a daily basis. It is believed that initially facing changes is not easy. As time goes by, new alternatives emerge and, in the course of daily experiences, the person with an ostomy establishes routines that facilitate care with the exchange and cleaning of the device. These adjustments should be understood as new rearrangements that will be part of health maintenance to avoid complications with the stoma'.

Changing the path of feces changes hygiene habits due to daily contact with feces in the process of frequent emptying and changing the collection bag. The lack of control in fecal elimination generates insecurity, causing the person with an ostomy to use the bathroom more often than others. Therefore, for safety, you should always have a spare collection bag for emergency exchanges, which can occur at any time.

The lack of adapted sanitary facilities interferes with the socialization of the person with an ostomy and can represent a frequent cause of isolation. In some cases, the person with an ostomy needs to reach down to the level of the toilet to empty the stool. The difficulty described is related to the fact that the level of the collecting equipment 
attached to the waist is above the level of the toilet. At the time of cleaning, when removing the feces from the collection bag, it is necessary to discard them in the vase, and with the impact it can eject the water out, contaminating the person and the environment, making it an unpleasant situation, since it is not It is possible to clean the stoma in a dirty environment ${ }^{9}$.

Furthermore, without an adapted bathroom, this cleaning routine can cause trauma, as many are in the kneeling position and suffer abrasions and lower back pain. In everyday life, in shared environments, this difficulty in sanitizing is greater due to unhealthy public places and can result in possible infections.

In the present study, participants claimed that collecting equipment represents one of the main challenges to be faced and, at the same time, it is inevitable, since its use is continuous. The specific materials for ostomy must be presented to the patient in the preoperative phase.

It was possible to observe some reports in this study of how much guidance in relation to stoma care and the use of specific material are essential. The quality of life of people with intestinal ostomy is conditioned to physical and emotional adjustments and the support of qualified professionals ${ }^{10}$.

Thus, it is necessary that the equipment is developed with the purpose of providing safety, comfort, mobility, practicality, protection of the peristomal skin and not allowing the emission of noise and odors. With the proper choice of material, indicated by the Stomatherapist nurse and according to your preferences, it is possible to return to daily activities and reintegrate socially ${ }^{11}$.

In fact, people with an ostomy can have complications, which causes fear of possible subsequent surgeries. Due to the anatomical change and the stoma being a fragile mucosa, special care is needed to avoid trauma, detachment, dermatitis, prolapse, hernia, retraction and others.

Participants complained of discomfort caused by the use of vehicle seat belts. Regardless of the side, for both the driver and the passenger, the seat belt presses on the stoma. Therefore, there is a concern to prevent trauma or unforeseen events of this nature. Aware of the risks of accidents, they remain vigilant. They start to avoid simple gestures, such as holding the child in their arms, riding a bicycle and taking a car, among other activities they performed before the operation.

Regarding work, in the present study, $80 \%$ of the participants do not have work activities, despite having an average age of 49 years, that is, they are in the productive phase of their lives. However, they stopped working after the ostomy and preferred to retire or receive some kind of government assistance. It was not possible to clarify whether this option is due to feelings of insecurity and challenges to return to work or because they chose to receive the benefit that may correspond to the same salary they received while working. Such choice can guarantee monthly financial income, but it can lead to idleness due to accommodation. In reality, work provides financial support and enables social inclusion. Productive activity for people with disabilities promotes feelings of happiness in many ways and can reduce social stigma ${ }^{12}$.

Participants in this research faced obstacles in the work environment. They often needed to use the toilet to empty the feces collection bag and, generally, work activities take place in collective environments, which makes the cleaning procedure difficult. This leads to isolation and the fear of suffering prejudice on the part of employers, who, by becoming aware of health conditions, can avoid hiring or remaining in the job ${ }^{13}$. Therefore, it is worth emphasizing the importance of the nurse's role in encouraging the return to work activities to reinforce the process of social inclusion, while respecting their new health condition.

As for eating habits, it is noticeable that they are used in search of well-being and to avoid some unpleasant problems, such as discomfort, involuntary elimination of gas, episodes of diarrhea and constipation. Furthermore, they can control the consistency and odor of the stool. People with ostomy do not have mechanisms that regulate the flow of feces, which makes eliminations continuous. Therefore, they seek alternatives to alleviate the difficulties arising from this new reality, regulating intestinal functioning through dietary control. This is reflected in the possibility of social acceptance.

Some foods cause the release of gases in the collecting equipment, causing discomfort and changes in body image. Dietary changes after the ostomy greatly affect the nutritional status, social and psychological relationships3. Therefore, people with an intestinal ostomy make a rigorous selection of foods as a method of controlling bowel function, whose purpose is to restore self-confidence. 
Food restrictions require multidisciplinary attention and monitoring to avoid nutritional imbalance. It is necessary to clarify doubts about food, such as myths and truths, to avoid undesirable consequences to health. The person with ostomy must have a normal and balanced diet, recognizing the foods that their body tolerates or not. The exclusion of food groups without proper guidance can harm nutritional and emotional status ${ }^{3}$.

The sudden change in body image breaks what had been built throughout life, interferes with the perception of one's own body, which is the result of individual experiences. Making a stoma can negatively change the ability to see yourself, distorting and diminishing your image and self-esteem ${ }^{14}$.

Generally, people crave physical perfection, want a beautiful body, aesthetically acceptable to social standards of beauty. In modernity, the representation of an ideal body has become popular, which favors the social inclusion of people who correspond to this standardization. However, people with ostomy, in the presence of the device in the abdominal wall, feel different regarding their sociocultural interaction. And so, they look for ways to adapt to the situation in which they find themselves, and tend to build new norms that distance them from the feeling of being different ${ }^{15}$.

Other studies confirm the results of this research, stating that in the process of adapting to physical changes, individuals change their routine and alter their appearance to hide the presence of the device ${ }^{4,8}$.In an attempt to hide the collecting device, they wear loose-fitting clothes and larger numbers than their bodies require.

In the present study, it was observed that the involuntary elimination of feces and gas causes insecurity and embarrassment among people with an intestinal ostomy. The fear of eliminating gases becomes a reason for social isolation, considering that it is unusual to eliminate gases in a public environment. In society there are rules that influence the act of evacuation, which since childhood is understood as something dirty and private. That's why they prefer to stay in more discreet and distant places from other people.

The conditions for living with an intestinal ostomy are very complex. Often motivated by fear of prejudice, the person does not comment and prefers to walk away to avoid questions from curious people. Collecting equipment has been stigmatized by society ${ }^{13}$, the perception of the equipment under the clothing causes frequent embarrassment related to body searches by security guards in public establishments, alleging that they are carrying stolen objects.

The second category deals with "strategies developed by people with ostomy in coping with changes". Thus, they can seek a healthy way to live with the new health condition for the rest of their lives, being resilient in the face of such a situation.

The participants' testimonies show the search for spirituality as one of the ways to have hope and help with defense mechanisms. In addition, reframing the understanding and acceptance of their new way of being, being and living with an ostomy. Resorting to God's support contributes to the individual's inner strengthening, makes it possible to interpret the health condition and helps withstand difficult times ${ }^{10,14}$.

When asked if they felt comfortable sharing with others about their ostomy, it was observed that they preferred not to comment with people from their social circle. This behavior is understandable, as people avoid talking about their intimacy, generally commenting only on the positive points of their experiences. Intimate issues are the responsibility of those involved to maintain the discretion to comment or not. Therefore, only family members very close to them are aware of their ostomy.

Generally, the person with ostomy notices the distance from some friends and may feel stigmatized ${ }^{13}$. Thus, they look for support at the meetings promoted by the category association. This has a positive influence, as it represents a space that seeks different types of resources, both material and technical information, which help in self-care. The meetings are a coping tool that is favorable to adaptation, as it is possible to express feelings, insecurities and fears. The association is seen by people with ostomy as a safe place where they can place their anxieties more freely, in the certainty of being understood by their peers. Therefore, support groups represent a participatory process that allows sharing similar experiences that help in social interaction ${ }^{10}$.

Although social support allows each one to face the current situation more easily, adaptation passes through the stages of grief, shock, disbelief, denial, rejection and anger. And it's a long and continuous individual process ${ }^{4,10}$. In this sense, it is necessary that professionals are prepared to fully assist people with ostomy.

The limitation of the present study was related to the number of participants. However, the results described contribute to reaffirm the findings of other studies. 


\section{CONCLUSION}

This study allowed the understanding of some meanings of what it is like to live with an ostomy. This condition requires a change in lifestyle and facing daily challenges. Despite the desire of some to resume leisure and work activities, they face obstacles that make them insecure, social isolation being inevitable. The main reasons are related to the adaptation of the collection bag in the abdomen, the fear of extravasation of feces, the lack of adapted toilets and the lack of information in society. Furthermore, flatulence, the location of the stoma and body image cause anxiety and fear of exposure in interpersonal relationships. Therefore, it is important for professionals to convey security and encourage positive attitudes that minimize conflicts arising from the ostomy.

What caught the attention were the reports of the participants about the fear of holding the child on their lap, running on a bicycle and using the car's seat belt that reaches the stoma with risks of crushing. Simple gestures for most humans, however, are not for those who live with an abdominal ostomy.

In the social sphere, embarrassing situations can arise due to the involuntary elimination of gases, noise and odor, which can generate feelings of shame and concern. Thus, they avoid traveling, playing sports, going to clubs, restaurants, cinemas, among others. These negative feelings often lead to reduced social interaction. And to adapt to physical changes and soften the feeling of being different, in an attempt to hide the collecting device, they wear loose-fitting clothes and larger numbers than their figure requires.

As for eating habits, the participants highlighted that, in their daily lives, they had to undergo strict dietary control in order to minimize the elimination of gases, improve the consistency and odor of feces.

Faced with these daily challenges, the person with ostomy develops strategies to overcome this new phase. However, they need help in this process and have specialized follow-up. Given the multiplicity of changes that the person will have to live with for the rest of their life, it is necessary to provide preparation for living with the ostomy, in order to facilitate self-care, acceptance and self-confidence.

It is believed that this research contributes to the nurse in integrated care for people with ostomy. Such care involves information about technical procedures and subjective issues such as qualified listening, seeking to understand their meanings and specificities. In addition to promoting the creation of bonds between professionals, patients and families, a condition that provides success in the process of adaptation and self-care. This requires a complex and subjective dimension, which is not limited to social, but also functional aspects, which, associated with individuality, lead to the impact of the results presented in the study.

\section{AUTHORS' CONTRIBUTION}

Conceptualization: Silva AL e Moraes RHG; Methodology: Silva AL, Vieira ABD, Moraes RHG e Mazoni SR; Writing - First Version: Moraes RHG, Vieira ABD e Mazoni SR; Writing - Review \& Editing: Moraes RHG, Vieira ABD, Mazoni SR, Silva AL e Kamada I; Supervision: Silva AL.

\section{DATA STATEMENT AVAILABILITY}

Data will be made available on request.

\section{REFERENCES}

1. Portaria n. 400 de 16 de novembro de 2009 (BR). Diretrizes Nacionais para a Atenção à Saúde das Pessoas Estomizadas no âmbito do Sistema Único de Saúde - SUS. Diário Oficial da União [periódico da internet], Brasília (DF). 18 nov 2009.

2. Santos VLC de G. Aspectos epidemiológicos dos estomas. ESTIMA, Braz J Enterostomal Ther. 2007;5(1):31-38. Available at: https://www.revistaestima.com.br/index.php/estima/article/view/207 
3. Selau CM, Limberger LB, Silva MEN, Pereira AD, Oliveira FS, Margutti KMM. Perception of patients with intestinal ostomy in relation to nutritional and life style changes. Textocontexto - enferm. 2019;28:e20180156. https://doi.org/10.1590/1980-265XTCE-2018-0156

4. Jacon JC, Oliveira RLD, Campos GAMC. Viver com estomia intestinal: autocuidado, sexualidade, convívio social e aceitação. Cuid Arte Enfermagem 2018;12(2):153-159. Available at: http://www.webfipa.net/facfipa/ner/sumarios/cuidarte/2018v2/153_159.pdf.

5. Silva AL, Kamada I, Sousa JB, Vianna AL, Oliveira PG. Singularidades da convivência do cônjuge e seu parceiro estomizado. ESTIMA, Braz J Enterostomal Ther. 2016;14(2):68-75. https://doi.org/10.5327/Z1806-3144201600020004

6. Bardin L. Análise de conteúdo. 70ª ed. Lisboa; 2011.

7. Ministério da Saúde (BR). Instituto Nacional de Câncer José Alencar Gomes da Silva. Estimativa 2018: incidência de câncer no Brasil. Rio de Janeiro: Ministério da Saúde; 2019.

8. Freire DA, Angelim RCM, Souza NR, Brandão BMGM, Torres KMS, Serrano SQ. Autoimagem e autocuidado na vivência de pacientes estomizados: o olhar da enfermagem. REME - Rev Min Enferm. 2017;21:e-1019. https://doi.org/10.5935/14152762.20170029

9. Capilla-Díaz C, Nieves CB, Hernández-Zambrano SM, Montoya-Juárez R,Morales-Asencio JM, Pérez-Marfil MN et al. Living With an Intestinal Stoma: A Qualitative Systematic Review. Qual Health Res. 2019;29(9):1255-65. https://doi. org/10.1177/1049732318820933

10. Maciel DBV, Santos MLSC, Souza NVDO, Fuly PSC, Camacho ACLF, Soares HPL. Qualidade de Vida de Pessoas com Estomias Intestinais Definitivos: uma Revisão Integrativa. Rev Enferm Atual In Derme. 2018;86(Edição especial). https://doi.org/10.31011/ reaid-2018-v.86-n.24-art.109

11. Spenazato RVS, Santos CRS, Morita ABPS, Paula MAB. Satisfação de pacientes com estomias intestinais quanto ao uso de equipamentos. ESTIMA, Braz J Enterostomal Ther. 2016;14(4):193-202. https://doi.org/10.5327/Z1806-3144201600040006

12. Teixeira FN, Souza NVDO, Silva PAS, Maurício VC, Costa CCP, Andrade KBS.O mundo do trabalho e as pessoas estomizadas: percepções e sentimentos. Cienc Cuid Saude 2016;15(1):69-76. https://doi.org/10.4025/cienccuidsaude.v15i1.27282

13. Barbosa G, Paschoalin HC, Greco RM, Dias SM. Vivências de pessoas com estomia no mundo do trabalho. ESTIMA, Braz J Enterostomal Ther. 2018;16:e0218. https://doi.org/10.30886/estima.v16.372_PT

14. Marques ADB, Amorim RF, Mesquita NS, Fontenele FMC, Pereira MLD, Moreira TMM. Significados atribuídos à percepção de ser-estomizado-no-mundo. ESTIMA, Braz J Enterostomal Ther. 2018;16:e3518. Available at: https://www.researchgate.net/ publication/330990374_Significados_atribuidos_a_percepcao_de_ser-estomizado-no-mundo

15. Albuquerque AFLL, Pinheiro AKB, Linhares FMP, Guedes TG. Tecnologia para o autocuidado da saúde sexual e reprodutiva de mulheres estomizadas. Rev Bras Enferm. 2016;69(6):1164-71. http://doi.org/10.1590/0034-7167-2016-0302 